\title{
Analisis Nilai Tambah Agroindustri Chips Jagung
}

(Analysis of Added Value of Corn Chips Agro-industry)

Syamsul Rahman

Fakultas Pertanian, Universitas Islam Makassar, Makassar

*Korespondensi dengan penulis (syamrah_uim@yahoo.com)

Artikel ini dikirim pada tanggal 20 Maret 2015 dan dinyatakan diterima tanggal 5 April 2015. Artikel ini juga dipublikasi secara online melalui www.journal.ift.or.id

Hak cipta dilindungi undang-undang. Dilarang diperbanyak untuk tujuan komersial.

Diproduksi oleh Indonesian Food Technologists $® ~ @ 2015$ (www.ift.or.id)

\begin{abstract}
Abstrak
Jagung dapat diolah menjadi berbagai produk baik untuk makanan pokok atau makanan selingan atau kudapan. Penelitian ini bertujuan untuk mendeskripsikan dan menganalisis nilai tambah dari agroindustri chips jagung sebagai salah satu produk hasil pertanian berbasis pedesaan. Penelitian ini dilaksanakan di Kelompok Wanita Tani Angggrek di Desa Kaloling Kecamatan Gantarangkeke Kabupaten Bantaeng. Penentuan obyek penelitian ditentukan secara sengaja (purposive sampling) mengingat Kelompok ini mempunyai kegiatan di bidang pengolahan hasil pertanian (agroindustri), terutama pengolahan jagung pipilan menjadi chips jagung. Metode analisis yang digunakan adalah untuk mengukur tingkat keuntungan yang dihasilkan dari agroindustri chips jagung, dihitung dengan menggunakan rumus pendapatan. Sedangkan untuk mengetahui nilai tambah yang dihasilkan dari agroindustri chips jagung digunakan rumus analisis nilai tambah. Selanjutnya, untuk mengetahui proses pengolahan (agroindustri) chips jagung dan kendala yang dihadapi kelompok usaha ini digunakan analisis deskriptif. Hasil penelitian menunjukkan bahwa agroindustri chips jagung memberikan keuntungan sebesar Rp 3.657.215. Sedangkan nilai tambah yang tercipta dari agroindustri chips jagung sebesar Rp 7.698, dengan imbalan tenaga kerja sebesar Rp 3.405 dan keuntungan sebesar Rp 4.294 dalam tiga kali proses produksi. Hal ini mengindikasikan bahwa agroindustri chips jagung dapat meningkatkan pendapatan dan kesejahteraan petani yang berskala rumah tangga (home industry).
\end{abstract}

Kata kunci: agroindustri, chips, jagung, nilai tambah

\begin{abstract}
Corn can be processed into various products both for staple foods or snack. The study aims to describe and analyze the added value of corn chips agro-industry as one of the rural-based agricultural products. The study was conducted at Kaloling Village Gantarangkeke District Regency of Bantaeng. Determination of the research object specified intentionally (purposive sampling) because Women Farmers Group of Anggrek has main activities in the processing of agricultural products (agro-industry) especially maize processing into corn chips. Analytical methods were used to measure the level of benefits arising from the agro-industry corn chips. Determination of the added value used formula added value analysis. Determination of processing of corn chips agro-industry and constraints faced by business groups used descriptive analysis. The results showed that corn chips agro-industry provided a profit of Rp. 3,657.215, while the added value from corn chips agro-industry was Rp. 7.698 with fee for labor was Rp. 3,405 and a profit was Rp. 4,294 within three times of production process. This indicated that the agroindustrial corn chips could increase farmers' income and welfare of the household scale (home industry).
\end{abstract}

Keywords : agro-industry, chips, corn, added value

\section{Pendahuluan}

Indonesia merupakan negara agraris yang luas lahan pertaniannya mencapai 107 juta hektar, dari total luas daratan Indonesia yang mencapai 192 juta hektar. Dari luas lahan pertanian tersebut, luas lahan jagung sekitar 3,35 juta hektar pada tahun 2004, dan mampu menghasilkan jagung sebanyak 11,22 juta ton (Hambali et al.,2006). Jagung sebagai bahan pangan pokok mempunyai nilai gizi yang cukup baik, selain kandungan karbohidratnya mencapai 63,60 persen juga mengandung lemak dengan asam lemak tak jenuh yang cukup tinggi, protein 7,90 persen, mineral dan vitamin termasuk kandungan vitamin A yang tinggi (440 SI) dibanding jenis biji-biji lainnya (Ahmadi, 2009). Namun potensi produksi dan kandungan gizi jagung sebesar dan sebaik itu belum dimanfaatkan secara optimal (Mahendradatta dan Tawali, 2008). Salah satu cara meningkatkan nilai tambah produk jagung adalah dengan mengolahnya menjadi berbagai macam produk olahan jagung (agroindustri). Agroindustri itu sendiri adalah suatu usaha untuk menciptakan suatu produk olahan dalam bentuk barang jadi maupun barang setengah jadi yang bahan baku utamanya merupakan produk pertanian (Soeharjono, 2001). Dengan kata lain, agroindustri merupakan suatu kegiatan industri yang memproses bahan baku pertanian menjadi bentuk lain yang lebih menarik dan memberikan nilai tambah serta dapat menciptakan lapangan kerja bagi masyarakat (Soekartawi, 1996).

Agroindustri penting dilakukan dalam rangka meningkatkan nilai tambah, terutama pada saat produksi melimpah dan harga produk rendah, juga untuk produk yang rusak atau bermutu rendah, maka disinilah saat yang tepat untuk mengolahnya lebih 
lanjut. Menurut Jumadi (2008) jagung dapat diolah menjadi berbagai produk olahan. Salah satu hasil olahan jagung yang disukai banyak konsumen adalah chips jagung atau kripik jagung (Mangunwidjaja, 2003). Proses pengolahan produk ini cukup sederhana sehingga berpeluang diadopsi oleh masyarakat pedesaan, terutama wanita tani sebagai industri rumah tangga (home industry).

Kegiatan agroindustri dinilai dapat meningkatkan nilai tambah. Nilai tambah yang diperoleh adalah selisih antara nilai komoditas yang mendapat perlakuan pada tahap tertentu dengan nilai pengorbanan yang digunakan selama proses produksi berlangsung (Langitan,1994).Selanjutnya, nilai tambah menunjukkan balas jasa untuk modal, tenaga kerja, manajemen perusahaan. Menurut Langitan (1994) salah satu kegunaan menghitung nilai tambah adalah untuk mengukur besarnya jasa terhadap pemilik faktor produksi. Hakikatnya nilai tambah merupakan nilai produksi dengan bahan baku dan bahan penunjang yang dipergunakan dalam proses produksi. Dengan demikian, nilai tambah dapat ditulis secara matematis sebagai berikut :

Nilai tambah $=f\{K, B, T, U, H, h, L\}$, dimana

$$
\begin{aligned}
& K=\text { kapasitas produksi } \\
& B=\text { bahan baku yang digunakan } \\
& T=\text { tenaga kerja yang diperlukan } \\
& U=\text { upah tenaga kerja } \\
& H=\text { harga output } \\
& h=\text { harga bahan baku } \\
& \text { L }=\text { nilai input lain }
\end{aligned}
$$

dari hasil perhitungan menggunakan rumus tersebut, maka didapat keterangan sebagai berikut :

a. Perkiraan nilai tambah (Rp)

b. Rasio nilai tambah terhadap nilai produk yang dihasilkan (\%)

c. Imbalan bagi tenaga kerja (Rp)

d. Rasio imbalan tenaga kerja terhadap nilai tambah (\%)

e. Perkiraan keuntungan yang diperoleh (Rp)

f. Rasio keuntungan terhadap nilai tambah, untuk mendapatkan nilai tingkat keuntungan yang diperoleh (\%)

Melihat potensi yang dimiliki oleh komoditas jagung untuk dijadikan berbagai macam produk olahan dalam rangka meningkatkan pendapatan masyarakat pedesaan, maka tujuan penelitian ini adalah mendeskripsikan proses pengolahan (agroindustri) jagung pipilan menjadi chips jagung dan menganalisis nilai tambah dari agroindustri chips jagung pada skala industri rumah tangga (home industry).

\section{Metode Penelitian}

Penelitian dilakukan di Kelompok Wanita Tani Anggrek yang terletak di Desa Kaloling Kecamatan Gantarang Keke Kabupaten Bantaeng Provinsi Sulawesi Selatan. Pemilihan tempat ini dilakukan secara purposive, karena kelompok ini kegiatan utamanya bergerak di bidang pengolahan hasil pertanian (agroindustri) khususnya agroindustri chips jagung (kripik jagung). Penelitian ini dilaksanakan pada Februari - April 2014.

\section{Pengambilan Data}

Jenis data yang digunakan dalam penelitian ini adalah data primer dan data sekunder. Data primer diperoleh dengan cara; observasi dan interview, yaitu wawancara langsung dengan pengelola dan pekerja dengan cara melakukan peninjauan langsung pada obyek penelitian dan menggunakan kuisioner sesuai kebutuhan yang telah dipersiapkan sebelumnya.

\begin{tabular}{|c|c|c|}
\hline No. & Variabel & Notasi \\
\hline 1. & $\begin{array}{l}\text { Hasil produk } \\
\text { (bungkus/hari) }\end{array}$ & $A$ \\
\hline 2. & Bahan baku (kg/hari) & $\mathrm{B}$ \\
\hline 3. & Tenaga kerja (H/hari) & $\mathrm{C}$ \\
\hline 4. & Faktor konversi (1:2) & $A / B=m$ \\
\hline 5. & $\begin{array}{l}\text { Koefisien tenaga kerja } \\
(3: 2)\end{array}$ & $C / B=n$ \\
\hline 6. & $\begin{array}{l}\text { Harga produk rata-rata } \\
\text { (Rp/bungkus) }\end{array}$ & $\mathrm{D}$ \\
\hline 7. & $\begin{array}{l}\text { Upah rata-rata } \\
\text { (Rp/hari) }\end{array}$ & $E$ \\
\hline 8. & $\begin{array}{l}\text { Harga bahan baku } \\
(\mathrm{Rp} / \mathrm{kg})\end{array}$ & $F$ \\
\hline 9. & $\begin{array}{l}\text { Sumbangan input lain } \\
(\mathrm{Rp} / \mathrm{kg})\end{array}$ & $\mathrm{G}$ \\
\hline 10. & $\begin{array}{l}\text { Nilai produk (4x6) } \\
\text { (Rp/bungkus) }\end{array}$ & $\mathrm{m} \times \mathrm{D}=\mathrm{K}$ \\
\hline 11. & $\begin{array}{l}\text { a. Nilai tambah (10-8 } \\
-9) \text { (Rp/bungkus) } \\
\text { b. Rasio nilai tambah } \\
(11 \mathrm{a} / 10)(\%)\end{array}$ & $\begin{array}{c}\mathrm{K}-\mathrm{F}-\mathrm{G}=\mathrm{I} \\
\mathrm{I} / \mathrm{K} \%=\mathrm{h} \%\end{array}$ \\
\hline 12. & $\begin{array}{l}\text { a. Imbalan tenaga } \\
\text { kerja }(5 \times 7) \\
\text { (Rp/bungkus) } \\
\text { b. Bagian tenaga kerja } \\
(12 a / 11)(\%)\end{array}$ & $\begin{array}{l}n \times K=p \\
p / 1 \%=q \%\end{array}$ \\
\hline 13. & $\begin{array}{l}\text { a. Keuntungan }(11 a- \\
12 a) \\
\text { b. Tingkat keuntungan } \\
(13 a / 11 a)(\%)\end{array}$ & $\begin{array}{l}l-p=r \\
r / l=s \%\end{array}$ \\
\hline
\end{tabular}
Sedangkan data sekunder diperoleh dari instansi terkait seperti Dinas Pertanian, Badan Ketahanan Pangan dan Penyuluhan Pertanian, Dinas Perindustrian dan Perdagangan, serta Biro Pusat Statistik (BPS) Kabupaten Bantaeng.

Tabel 1. Format Perhitungan Analisis Nilai Tambah

Keterangan: "bahan penolong," imbalan bagi modal dan manajemen. Sumber: Langitan (1994)

\section{Analisis Data}

Metode analisis yang digunakan adalah untuk mengukur tingkat keuntungan yang dihasilkan dari agroindustri chips jagung, dihitung dengan menggunakan rumus pendapatan yaitu menggunakan langkah-langkah sebagai berikut; a) Biaya total (TC = TVC + TFC), b) Penerimaan $(T R=P \times Q)$ dan $c)$ 
Keuntungan $(\pi \mathrm{T}=\mathrm{TR}-\mathrm{TC})$. Sedangkan untuk mengetahui nilai tambah yang dihasilkan dari agroindustri chips jagung digunakan rumus analisis nilai tambah sebagaimana tampak pada Tabel 1 .

Selanjutnya, untuk mengetahui proses pengolahan (agroindustri) chips jagung dan kendala yang dihadapi kelompok usaha ini digunakan analisis deskriptif.

\section{Hasil dan Pembahasan}

\section{Proses Pengolahan Chips Jagung}

Tahapan proses pengolahan atau pembuatan chips jagung dalam satu kali proses produksi seperti ditunjukkan pada diagram alir (flow chart) (Gambar 1).

Anonim (2007) menjelaskan tahapan proses pengolahan jagung pipilan menjadi chips jagung sebagai berikut ; Pertama, menimbang seluruh bahan baku dan bahan tambahan (penolong) yang akan digunakan. Kedua, membuat larutan kapur dengan mencampur $250 \mathrm{~g}$ kapur sirih ke dalam 25 liter air, bagian yang kasar di buang. Ketiga, larutan diaduk kemudian ditambahkan ditambahkan $250 \mathrm{~g}$ garam dan 3 sendok makan minyak goreng. Keempat, masukkan jagung ke dalam larutan tersebut dan rebus sampai mendidih, kemudian 2 jam setelah mendidih dihentikan, kemudian diangkat.

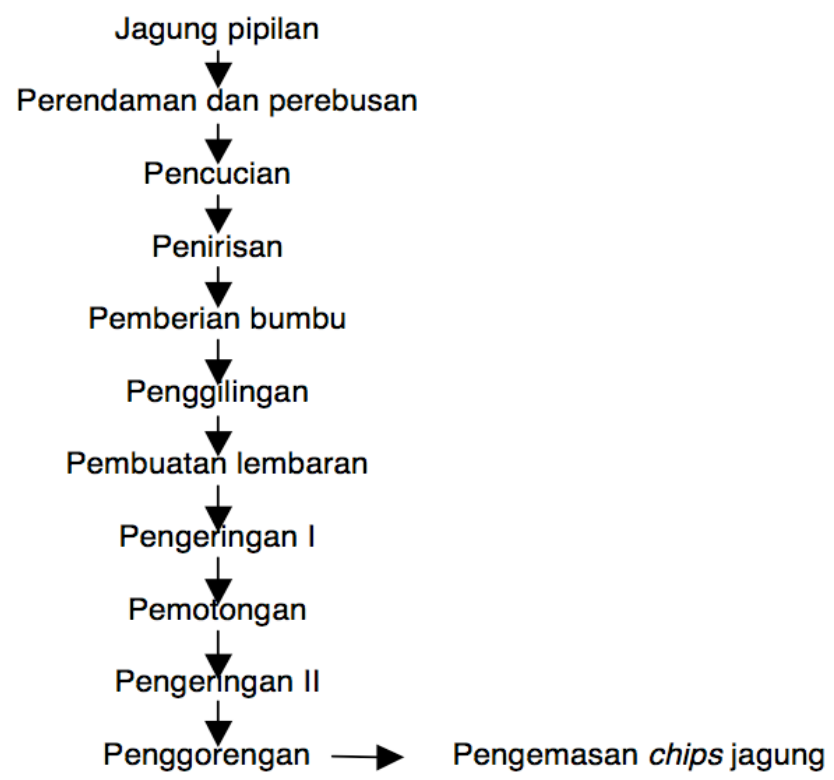

Gambar 1. Flow chart pengolahan chips jagung

Selanjutnya tahapan kelima, jagung direndam dalam air kapur selama 12 jam dan sering diaduk. Keenam, membuang air rendaman jagung kemudian mencucinya beberapa kali minimal 5 kali sampai jagung bersih dari kapur, lalu ditiriskan pada wadah yang telah disediakan. Ketuju, menambahkan bawang putih $150 \mathrm{~g}$ dan $15 \mathrm{~g}$ merica halus pada jagung yang telah ditiriskan. Kedelapan, menggiling jagung dan bumbu sampai liat dan halus menggunakan alat penggiling daging.

Kemudian tahapan kesembilan, yaitu membuat adonan menjadi lembaran tipis-tipis dengan ketebalan 1 $\mathrm{mm}$ dengan penggilas/penggiling bambu atau kayu.
Lalu dijemur sebentar sampai setengah kering agar rekatnnya cukup kuat lalu memotongnya dengan ukuran $2 \times 2 \mathrm{~cm}$, atau setelah menjadi lembaran tipis langsung dipotong sesuai ukuran yang diinginkan. Kesepuluh, menjemur lembaran tipis-tipis jagung hingga kadar air $8 \%$ atau sudah muda dipatahkan. Kesebelas, menggoreng chips dengan minyak panas dengan suhu $170^{\circ} \mathrm{C}$ selama 15 detik, kemudian ditiriskan. Keduabelas, pada suhu chips masih hangat ditaburi bahan perasa kemudian diratakan, dan tahapan ketigabelas setelah dingin, chips kemudian dikemas dengan kemasan plastik yang telah disiapkan.

\section{Analisa Biaya dan Pendapatan}

Dalam satu proses produksi banyak sekali biayabiaya yang harus dikeluarkan, demikian halnya dengan agroindustri chips jagung. Agroindustri ini memerlukan berbagai biaya dalam proses produksinya, yang mana biaya-biaya ini dapat dibedakan menjadi dua yaitu biaya tetap dan biaya variabel. Besar kecilnya biaya yang dikeluarkan tiap unit kegiatan berbeda-beda tergantung cara pengalokasian, produktivitas, dan besarnya produksi (Muljadi, 1995).

Hasil analisa data diperoleh biaya variabel (TVC) sebesar Rp 2.718.000 dan biaya tetap (TFC) sebesar Rp 824.785 sehingga total cost dalam proses pengolahan chips jagung sebesar Rp 3.542 .785 yang merupakan hasil penambahan 2 komponen biaya yaitu biaya variabel dan biaya tetap sebesar Rp 124.785 . Hal ini berarti selama 1 bulan terjadi 24 kali proses produksi dengan mengeluarkan biaya sebesar $\mathrm{Rp}$ 3.542.785. Untuk penerimaan (total revenue) selama 1 bulan terjadi 24 kali proses produksi pada home industri chips jagung mendapatkan penerimaan sebesar $R p$ 7.200.000 yang didapatkan dari harga jual chips dengan jumlah produksi setiap harinya.

Selanjutnya dari penerimaan selama 1 bulan $(R p$ 7.200.000) dikurangi dengan total biaya yang dikeluarkan selama $24 \times$ proses produksi (Rp 3.542.785) maka akan didapatkan keuntungan usaha sebesar Rp 3.657.215. Dilihat dari skala industri yang tergolong industri rumah tangga (home industry), maka dapat dikatakan bahwa usaha chips jagung sangat menguntungkan untuk terus dikembangkan ke depan.

\section{Analisis Nilai Tambah Chips Jagung}

Analisis nilai tambah agroindustri chips jagung untuk satu kali proses produksi di peroleh hasil sebanyak 300 bungkus. Untuk menghasilkan produk sebanyak itu dibutuhkan bahan baku jagung pipilan sebanyak $5 \mathrm{~kg}$ dengan harga Rp 1.700/kg, kapur sirih $250 \mathrm{~g}$ dengan harga Rp 500, bawang putih $15 \mathrm{~g}$ dengan harga $\mathrm{Rp} 1.500$, garam $250 \mathrm{~g}$ dengan harga $\mathrm{Rp} 500$, merica sebanyak $15 \mathrm{~g}$ harga Rp 500, minyak tanah 1,5 liter dengan harga $\mathrm{Rp} 3.000$, minyak goreng 1,5 liter harga Rp 8.000, kemasan plastik 250 pak harga Rp 100/pak, bahan perasa 3 pak dengan harga Rp 1.500/pak, dan air $0,5 \mathrm{~m}^{3}$ dengan taksiran harga $\mathrm{Rp}$ $1.500 / \mathrm{m}^{3}$.

Harga per 1 bungkus chips jagung adalah Rp 1.000 , dalam agroindustri chips jagung tersebut 
melibatkan tenaga kerja 2 orang untuk membantu proses produksi. Koefisiaen tenaga kerja sebesar 0,227 . Nilai ini menunjukkan bahwa untuk melakukan proses produksi $100 \mathrm{~kg}$ bahan baku diperlukan 20 hari kerja. Faktor konversi di dapatkan dari perbandingan antara hasil produksi dengan jumlah bahan baku yang digunakan dalam setiap kali proses produksi yaitu sebesar 33,998. Dengan harga chips jagung rata-rata Rp 1.000, maka didapatkan nilai produk sebesar $R p$ 33,998. Sumbangan input lain walaupun hanya sebagai bahan tambahan, tetapi mutlak digunakan yaitu sebesar Rp 7.500. Bahan input lain yang digunakan adalah bahan kapur sirih, bawang putih, merica, bahan perasa, garam, dan air.

Nilai tambah yang didapatkan dari agroindustri chips jagung adalah $\mathrm{Rp} 7.698$ dengan rasio nilai tambah sebesar 22,6 persen. Rasio nilai tambah terhadap nilai produk sebesar 22,6 persen diperoleh dari pengurangan harga bahan baku dengan sumbangan input lain mengandung imbalan terhadap tenaga kerja langsung dan keuntungan yaitu imbalan bagi modal dan manajemen. Imbalan tenaga kerja langsung sebesar $\mathrm{Rp} 3.405$ yaitu sebesar 44,23 persen. Prosentase ini lebih besar dibandingkan dengan prosentase imbalan bagi modal dan manajemen. Sehingga prosentase keuntungan dari agroindustri chips jagung terhadap nilai produk sebesar 55,76 persen. Jika dilihat secara keseluruhan, distribusi nilai tambah terhadap tenaga kerja langsung adalah cukup besar.

\section{Kesimpulan}

Penerimaan selama satu bulan untuk 24 kali proses produksi sebesar $\mathrm{Rp} 7.200 .000$ dikurangi dengan total biaya sebesar Rp 3.904.785 sehingga didapatkan keuntungan usaha sebesar Rp 3.657.215. Dilihat dari skala industri, agroindustri chips jagung menguntungkan dan tergolong sebagai industri rumah tangga (home industry). Sedangkan nilai tambah yang tercipta pada agroindustri chips jagung sebesar Rp 7.698 dengan imbalan tenaga kerja $\mathrm{Rp} 3.405$ dan keuntungan sebesar Rp 4.294 setiap kali proses produksi.

\section{Daftar Pustaka}

Ahmadi, 2009. Pelatihan Pengolahan Aneka Chips, Kripik, Kerupuk, Stik dan Olahan Pangan lain. Materi Pelatihan disampaikan dalam rangka Program Nasioaal Pemberdayaan Masyakat Pedesaa di Kabupaten Bantaeng.

Anonim, 2007. Pengolahan Produk dengan Bahan Baku Jagung Pipilan. Materi Pelatihan dan Pendampingan Masyarakat. Lembaga Bali Cemerlang Indoguna. Kuta Bali.

Hambali et al, 2006. Membuat Aneka Olahan Jagung. Penebar Swadaya Jakarta. Cet I.

Jumadi, 2008. Pengkajian Teknologi Pengolahan Tortila Jagung. Buletin Teknik Pertanian. Vol 13 No. 2 Hal 73- 74.

Langitan, 1994. Analisis Nilai Tambah Produk Minuman Segar Susu Kedelai. Jurusan Sosial Ekonomi Pertanian IPB Bogor.

Mahendradatta dan Tawali, 2008. Jagung dan Diversifikasi Produk Olahannya. Masagene Press. Pusat Kajian Makanan Tradisional Universitas Hasanuddin Makassar.

Mangunwidjaja, 2003. Teknologi dan Diversifikasi Pengolahan Jagung. Makalah Temu Usaha Perusahaan Jagung. Direktorat Jendral Industri Kimia, Agro dan Hasil Hutan. Departemen Perindustrian dan Perdagangan RI, Bandar Lampung.

Muljadi, 1995. Evaluasi Proyek. Liberty Yokyakarta.

Soekartawi, 1996. Agroindustri. Raja Grafindo Persada, Jakarta.

Soeharjono, 2001. Konsep dan Ruang Lingkup Agroindustri. Kumpulan Makalah Agribisnis Jurusan Sosial Ekonomi Pertanian IPB, Bogor. 